UDK: 338.488:005.57-027.233]:338.48-052

Izvorni znanstveni rad

\title{
ISPITIVANJE STUPNJA ZADOVOLJSTVA TURISTA KOMUNIKACIJSKIM KOMPETENCIJAMA TURISTIČKIH VODIČA
}

\section{Jasmina Gržinić}

Fakultet ekonomije i turizma „Dr. Mijo Mirkovic“ Sveučilište Jurja Dobrile u Puli Republika Hrvatska jasmina.grzinic@unipu.hr

Moira Kostić Bobanović

Fakultet ekonomije i turizma „Dr. Mijo Mirkovic““ Sveučilište Jurja Dobrile u Puli Republika Hrvatska moira.kostic.bobanovic@unipu.hr 


\section{SAŽETAK}

Ovim pilot istraživanjem analiziraju se veze između komunikacijskih kompetencija turističkih vodiča i zadovoljstva turista vođenim turama u nekoliko gradova Istarske županije. Pomoćni cilj rada je utvrditi korelaciju između komunikacijskih vještina vodiča, te spola igodina iskustva u radu. Svrha istraživanja je ukazati na propuste verbalne i neverbalne kompetencije vodiča tijekom vođenja tura. Za potrebe istraživanja prikupljeni su podaci od 283 ispitanika (turista) odabranih destinacija. Ispitanicidolazesrazličitih emitivnih tržišta. Rezultati istraživanja ukazuju na potrebu poboljšanja verbalnih vještina vodiča, kao i neverbalne komunikacije, poput pristupačnosti i sposobnosti razvoja prijateljskih odnosa s klijentom. Doprinos istraživanja je unaprjeđenje spoznaja u području interdisciplinarnih istraživanja (turizam i kultura). Rezultati istraživanja predstavljaju transfer znanja o očekivanim kompetencijama ispitanika i utjecaju na zadovoljstvo korisnika u svrhu unaprjeđenja kvalitete rada medijatora u turizmu i promotora destinacija.

Ključne riječi: turistički vodiči, verbalne kompetencije, neverbalne kompetencije, turisti, stupanj zadovoljstva. 


\section{UVOD}

Kvaliteta kadrova u procesu realizacije paketa ponuda (vodiča i predstavnika u destinacijama) u ovom se istraživanju prati kroz istraživanja njihovih verbalnih i neverbalnih komunikacijskih vještina. Glavna hipoteza rada (H0) je da su verbalna i neverbalna komunikacija važna obilježja vodiča turističkih tura koja utječu na zadovoljstvo posjetitelja. Pomoćnom hipotezom (H1) želi se provjeriti postoji li povezanost između komunikacijskih vještina i spola i iskustva turističkih vodiča.

Potaknuti nedovoljnim istraživanjima kompetencija u hrvatskom turizmu prikupljeni su podaci o zadovoljstvu turista kompetencijama vodiča u okviru vođenja čiji su bili sudionici. Dosadašnja istraživanja vezana su za postignutu razinu obrazovanja s ukazom na nedostatke programa i direktiva (Mizzi, 2009; Gregorić i sur., 2017), kao i s aspekta izazova koji se stavljaju pred kadrove u turizmu (Bartoluci, Budimski, 2010; Gorenak M., Gorenak I., 2012).

Do novih znanstvenih spoznaja u ovom radu došlo se formiranjem sljedećih istraživačkih pitanja:

(P1) Koliko su, prema mišljenju turista, turistički vodiči učinkoviti u provođenju verbalnih komunikacijskih vještina?

(P2) Koliko su, prema mišljenju turista, turistički vodiči učinkoviti u provođenju neverbalnih komunikacijskih vještina?

(P3) Postoji li povezanost između verbalnih i neverbalnih komunikacijskih vještina te spola i iskustva u radu turističkih vodiča?

Kod verbalnih kompetencija analizirani su napori uloženi u odabir jezika i izražavanje ideja koje su slušatelju razumljive, te teme usredotočene na dijeljenje i razumijevanje zemlje i kulturnog podrijetla. Neverbalno ponašanje obuhvaća pritom osmijeh, ugodan izraz lica, izravan kontakt očima, te uključenost $\mathrm{u}$ interakciju kroz obraćanje pažnje i kimanje glavom, te nagnutost prema drugoj osobi. Istraživanjem se obuhvatio spol i dob vodiča radi utvrđivanja povezanosti s komunikacijskim vještinama.

Prvi dio rada ukazuje na dosadašnje teorijske spoznaje s aspekta uloge vodiča u vođenju turističkih tura, te uloga vodiča kao medijatora prema korisniku usluge $\mathrm{u}$ turizmu. $\mathrm{U}$ drugom dijelu prezentiraju se rezultati istraživanja verbalnih $\mathrm{i}$ neverbalnih komunikacijskih vještina turističkih vodiča, provjeravaju postavljene hipoteze i sublimiraju zaključci. 


\section{DOSADAŠNJE SPOZNAJE}

Turistička vođenja su atraktivna, korisna, ali često zanemarena u istraživanjima (Maki sur., 2011).Znanja su u ovom području razvoja turizma još uvijek nedostatna (Ön Esen, Gülmez, 2017). Istraživanja pokazuju da turistički vodiči temeljem medijacije, interpretacije, informiranja i prezentacije destinacije čine kritičnu točku razvoja destinacijskog imidža (Malitoni Chilembwe, Mweiwa, 2014). Većina ljudi ulazi u aktivnost vođenja i ako nije dio turističkih paket aranžmana tako da budu uključeni već pri posjetu lokalitetima i turističkim resursima atrakcijama (Widtfeldt Meged, 2010). Kreativni turizam i specijalizirane ponude postaju nova strategija kulturnih destinacija (Domšić, 2013). Pažljivo odabranim tehnikama turistički bi vodič trebao na pravi način predstaviti relevantnu građu, što destinaciji daje dublje značenje u očima turista i budi znatiželju da se detaljnije upozna $s$ njegovim sadržajima (Poria i sur., 2009; Ferguson i sur., 2016).

Prema Gevi i Goldmanu (1991) učinkovitost vodiča važan je čimbenik uspjeha turističke ture. Njihov posao je osigurati da gosti uživaju u zanimljivoj interpretaciji i prezentaciji određene destinacije ili turističke atrakcije.

Kako bi turistička ponuda jedne destinacije bila potpuna, važno je imati turističke vodiče koji će turistima pružati usluge interpretacije prirodnih rijetkosti i ljepota, te cjelokupnu kulturu posjećene destinacije. Turistički vodič kao pružatelj usluga je u direktnom kontaktu s turistom, ostavlja trajan dojam, te ima važnu ulogu u turističkom iskustvu na odredištu (Lopez 1980; Mossberg 1995).

Izazove udovoljavanja turističkim iskustvima kroz dizajn i isporuku istih analiziraju Ritchie i Hudson (2009) ističući teorijsku i upravljačku dimenziju turističkog iskustva. Prema Tilotami (2019) profesionalne vještine i ponašanje doprinose turističkom zadovoljstvu. Cohen (1985) analizira uloge turističkih vodiča u svojstvu tragača i mentora medijatora koji ima četiri glavne uloge: instrumentalnu, socijalnu, interakcijsku i komunikativnu.

Glavna odgovornost turističkog vodiča je pretvoriti iskustvo turista u ugodu, a informacije učiniti dostupnima na zabavan, ali kulturno prihvatljiv način (Boyle, Arnott, 2004). Iako istraživači ističu da su vođene ture često stereotipne, one mogu uz korištenje novih vještina u komunikaciji udovoljiti zahtjevima turističkog tržišta za doživljajima i novim iskustvima (Zillinger i sur., 2012). Turistički vodiči pomoću vođenih tura omogućuju prikupljanje povratnih informacija i razvoj vještina ophođenja s klijentima (Hsu i sur., 2009). Heung (2008) provodi istraživanje na uzorku od 431 turista koji su korisnici usluga turističkog paketa u Hong Kongu. Utvrđena su četiri čimbenika utjecaja na zadovoljstvo korisnika i to; "Profesionalni stav i sposobnost", "Prezentacijska i komunikacijska sposobnost", "Profesionalno 
znanje" i "Osobni integritet". Zhang i Chow (2004) procjenjuju performanse turističkih vodiča prema percepciji odlaznih posjetitelja. Identificirano je dvadeset relevantnih atributa kvalitete usluge turističkog vodiča. Rezultati ukazuju na zadovoljstvo klijenata profesionalnim vještinama, razinama pouzdanosti i jezičnim sposobnostima, te na izazove $s$ aspekta sposobnosti rješavanja problema.

Nalazi empirijske studije temeljene na 15 vođenih obilazaka ističu ranjivost agencije na relaciji odnosa tvrtka-vodič-klijent (Geva, Goldman, 1991). Turistički vodič mora imati dobro razvijene komunikacijske vještine, biti ljubazan, strpljiv, samopouzdan, a također i odgovoran, samostalan, kreativan, snalažljiv, te emocionalno stabilan (Weiler, Black, 2014).

Gali i Aulet (2019) navode da je komunikacija između turista i turističkih vodiča uspješna kada ljudi uistinu čuju poruku koju želimo prenijeti. Također, zaključuju da stručna osoba treba biti otvorena za sva pitanja, prilagodljiva uzrastu posjetitelja, pokazati i ukazati na zanimljive činjenice o prezentiranim temama i objektima.

Odgovornost za postizanje zadovoljstva sudionika uglavnom je povjerena vodiču jer vođenje prilagođava individualnim potrebama i preferencijama. Sharma (2013) ukazuje na potrebu praćenja načina vođenja s ciljem budućih dizajniranja istih. Uz sve to potrebno je dodati osmijeh, očni kontakt, govor tijela, magiju, iniciranje kontakta i kreativna uslužna rješenja (Borrie, 1999). Prema Boyesu i suradnicima (2009) držanje tijela je vrlo važno u komunikaciji s drugim ljudima. Izrazom lica osoba komunicira informaciju iz koje komunikacijski partner može brzo zaključiti o unutarnjem stanju osobe, te sukladno tome prilagoditi svoje ponašanje (Smith i sur., 2005). Turistima je bitan kontakt očima koji ima tri važne uloge u komunikaciji: izražavanjeemocija, nadziranjeponašanja drugeosobei reguliranjetijekakonverzacije (Kendon, 1967; Burgoon, 2016). Brojni istraživači su došli do zaključka da pravilan odabir jezika, vanjski izgled i uporaba humora pozitivno utječu na zadovoljstvo turista prilikom vođenja turističkih tura osim poznavanja itinerera, potreba klijenata i lokalnih vrijednosti (Bowie, Chang, 2005; Chang, 2014; Le Nguyen, 2015; Tu i sur., 2019; Cheng i sur., 2020). Prema Rijavec i Miljković (2002) pod vanjskim izgledom podrazumijevamo odjeću, frizuru, njegu i higijenu tijela, te držanje i ponašanje. $U$ svojem radu Tsai i suradnici (2016) posebice naglašavaju važnost vanjskog izgleda i držanja tijela turističkih vodiča prilikom vođenja turističkih tura. Prema Pšunder (2002) u međuljudskim odnosima neverbalna komunikacija ima brojne funkcije, i to ne samo kroz emocionalni izražaj, već i onaj društveni, u vidu međuljudskih aktivnosti kao dijela društvenog ponašanja.

Posjetitelji žele posebne doživljaje i transformativna iskustva (Reisinger, 2013; Tomljenović, Ateljević; 2015). Sve je veći broj autora koji analiziraju turističke 
vodiče s aspekta komunikatora i posrednika iskustva (Black, Ham, 2005; Huang, Wang, 2007; Pearce, 2011; Kang, Gretzel, 2012; Weiler, Black, 2014).

Među domaćim autorima, kao i autorima uže regije, znatno je manji broj radova pisanih na ovu temu što ukazuje na značaj ovog istraživanja. Uglavnom su provedena istraživanja vezana za postignutu razinu obrazovanja s ukazom na nedostatke programa i direktiva (Mizzi, 2009; Gregorić i sur., 2017), kao i s aspekta izazova koji se stavljaju pred kadrove u turizmu (Bartoluci, Budimski, 2010; Gorenak M., Gorenak I., 2012). Potrebno je uspostaviti sustav praćenja koji će osigurati visoke standarde pružanja usluga od strane turističkih vodiča, tako rijetko zastupljeno u međunarodnoj znanstvenoj literaturi (Ap, Wong, 2001).

\section{METODOLOGIJA ISTRAŽIVANJA}

U ovom se poglavlju podrobno opisuje metodologija provedenog istraživanja: uzorak, upitnik korišten u istraživanju, te sam istraživački postupak. Korišten je kombinirani metodološki pristup, anketni upitnik distribuiran na lokaciji.

\section{UZORAK}

$\mathrm{U}$ istraživanju su sudjelovali turisti i turistički vodiči koji su u periodu provođenja anketnog upitnika, u, rujnu 2019. godine, boravili u Istarskoj županiji. Isti su bili sudionici vođenih tura u nekoliko gradova Istarske županije i to Pula, Poreč i Rovinj. Gradovi Rovinj i Poreč su nakon Dubrovnika, koji broji više od 4 milijuna noćenja, najposjećeniji hrvatski gradovi u 2019. godini (HTZ; 2019).

Ispitani su inozemni posjetitelji koji su slušali vođenja turističkih tura na engleskom jeziku. Uzorkom u istraživanju obuhvaćeno je ukupno 291 sudionika, od toga 283 turista koji su upitnik valjano popunili $(94,8 \%)$ i 8 turističkih vodiča (kao medijatora). Četiri turistička vodiča različitih spolova, koja su imala manje od dvije godine iskustva u vođenju turističkih tura, vodili su turiste u gradu Rovinju, dok su oni s višegodišnjim iskustvom vodili turiste po gradovima Puli i Poreču. Ujedno su licencirani vodiči za Istarsku županiju, a djelatnost vođenja ne predstavlja njihov izvor prihoda.

Opis broja i postotaka udjela sudionika s obzirom na spol nalazi se u Tablici 1. U uzorku turista zastupljeniji je ženski spol 169 (59,7 \%) u odnosu na muški $114(40,3 \%)$. U istraživanju je sudjelovalo 8 turističkih vodiča; od toga $4(50,0 \%)$ ženskog spola i 4 (50,0 \%) muškog. 
Tablica 1. Broj i postotak sudionika s obzirom na spol

\begin{tabular}{ccccc}
\hline \multirow{2}{*}{ Spol } & \multicolumn{2}{c}{ Turisti $(\mathrm{n}=283)$} & \multicolumn{2}{c}{ Turistički vodiči $(\mathrm{n}=8)$} \\
\cline { 2 - 5 } & $\mathrm{N}$ & $\%$ & $\mathrm{~N}$ & $\%$ \\
\hline \multirow{2}{*}{ Ženski } & 169 & 59,7 & 4 & 50 \\
\hline Muški & 114 & 40,3 & 4 & 50 \\
\hline
\end{tabular}

Turistički vodiči koji su sudjelovali u ovom istraživanju prošli su edukaciju i položili, uz stručni ispit za turističke vodiče, i ispit iz poznavanja engleskog kao stranog jezika.

Tablica 2. pruža uvid u broj i postotak (udio) turističkih vodiča s obzirom na godine iskustva u radu. Četiri turistička vodiča imala su do dvije godine rada u struci, te isti broj tri i više godina iskustva rada kao turistički vodiči.

Tablica 2. Broj i postotak turističkih vodiča s obzirom na godine iskustva u radu

\begin{tabular}{ccc}
\hline & $\mathrm{N}$ & $\%$ \\
\hline Do 2. god. & 4 & 50 \\
\hline 3 i više god. & 4 & 50 \\
\hline
\end{tabular}

Nakon vođenja turističkih tura, istraživači su uz pomoć turističkih vodiča ukratko dali upute o svrsi ispitivanja, proceduri i temi ispitivanja, te zamolili turiste da ga ispune. Anketni upitnik je bio anoniman, napisan na engleskom jeziku. Ispitanici su zamoljeni da napišu spol, a zanimljivo je, da je veliki broj ispitanika napisao ime i zemlju iz koje dolazi. Neki ispitanici napisali su i komentar zahvale turističkim vodičima na stručnom i zanimljivom vođenju uz poruke da će se vidjeti i naredne godine. Ispitanici su mogli odvojiti vrijeme za samostalno ispunjavanje upitnika (vrijeme trajanja u prosjeku $15 \mathrm{~min}$.) što je omogućilo da odgovaraju objektivno i bez pritiska, uzimajući u obzir da prisutnost istraživača zna utjecati na neiskrene i naizgled očekivane odgovore. 


\section{DIZAJN ISTRAŽIVANJA}

Ispitivanje je provedeno pomoću anketnog upitnika pogodnog za deskriptivna istraživanja. Za potrebe istraživanja korišten je prilagođen upitnik o verbalnim i neverbalnim komunikacijskim vještinama (Martin i sur., 1994). Model je prilagođen što je i uobičajeno u kulturološkim istraživanjima. U prvotnom modelu bile su ponuđene dvije verbalne i tri neverbalne dimenzije komunikacije. Izmjena prvotnog modela je u spajanju tri varijable neverbalne dimenzije u dvije. Varijable "poise“ $i$,attentiveness” ujedinjene su pod nazivom Vanjski izgled i držanje tijela i time prilagođene kulturološkim posebnostima i jeziku istraživanja. Verbalne dimenzije u istraživanju nisu izmijenjene.

Sudionici su zamoljeni ocijeniti stupanj učinkovitosti turističkih vodiča u provođenju verbalnih i neverbalnih komunikacijskih vještina na skali od $1-5(1=$ uopće se ne slažem, 5 = potpuno se slažem).

Tablica 3. Verbalne dimenzije

\begin{tabular}{|c|c|}
\hline Kompetencije & Varijable \\
\hline \multirow{4}{*}{ Verbalne } & Odabir jezika \\
\hline & $\begin{array}{l}\text { Korištenje odgovarajuće gramatike, jasno prezentiranje ideja, pažljivo } \\
\text { odabiranje riječi, jasan izgovor, humor, izbjegavanje slenga }\end{array}$ \\
\hline & Prezentacija kulturne i prirodne baštine \\
\hline & $\begin{array}{c}\text { teme usredotočene na dijeljenje i razumijevanje zemlje i kulturnog podrijetla, } \\
\text { npr. razgovarati i dijeliti pozitivne informacije o svojoj zemlji, pokazati interes } \\
\text { o drugim zemljama }\end{array}$ \\
\hline \multirow{4}{*}{ Neverbalne } & Ponašanje koje zahtjeva interakciju \\
\hline & $\begin{array}{c}\begin{array}{c}\text { osmijeh, ugodan izraz lica, izravan kontakt očima, obraćanje pažnje, kimanje } \\
\text { glavom }\end{array}\end{array}$ \\
\hline & Vanjski izgled i držanje tijela \\
\hline & prikladna tjelesna prezentacija; izgled, držanje \\
\hline
\end{tabular}

Modelom se ukazuje na povezanost vođenja turističkih vodiča sa zadovoljstvom posjetitelja. Dosadašnji teorijski doprinosi o turističkim vodičima, kompetencijama i zadovoljstvu posjetitelja identificirani su kroz model sa svrhom provjere postavljenih hipoteza. Intencija istraživača je dobivanje odgovora na istraživačka pitanja u skladu s postavljenim ciljevima. 


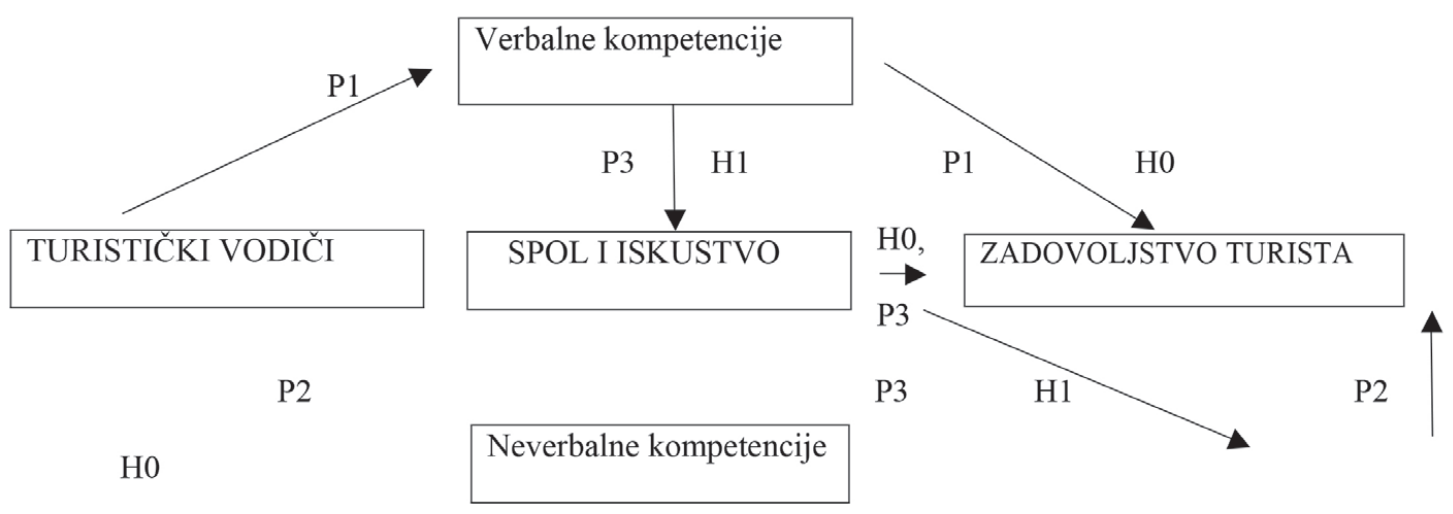

Dijagram 1. Model istraživanja

Model bi trebao biti doprinos istraživanjima vještina vodiča i turističkog zadovoljstva zbog porasta broja turista u međunarodnom turizmu, a ujedno i izvor za buduća longitudinalna istraživanja radi prikupljanja podataka o navedenim odnosima kroz vrijeme.

\section{REZULTATI ISTRAŽIVANJA}

Neverbalne i verbalne dimenzije provjerili su u međunarodnom kontekstu, zbog pouzdanosti, istraživači Martin i suradnici (1994). Uvidom u podatke prikazane u Tablici 4. možemo utvrditi da je koeficijent pouzdanosti (Cronbachov alfa) instrumenata bio zadovoljavajuće visok. Sve dimenzije komunikacijskih vještina pokazale su visoku razinu pouzdanosti u rasponu od 0,85 do 0,88.

Tablica 4. Koeficijent pouzdanosti

\begin{tabular}{cc}
\hline Komunikacijske vještine & Cronbach Alfa \\
\hline Verbalna dimenzija & \\
\hline Odabir jezika & 0.87 \\
\hline Prezentiranje kulturne i prirodne baštine & 0.85 \\
\hline Neverbalna dimenzija & \\
\hline Neverbalno ponašanje koje zahtjeva interakciju & 0.87 \\
\hline Vanjski izgled i držanje tijela & 0.88 \\
\hline
\end{tabular}

Nakon prikupljanja svih podataka uslijedila je statistička analiza varijabli obuhvaćenih istraživanjem što je predmet rasprave narednog poglavlja. Statistička analiza obaju upitnika provedena je pomoću programskog paketa SPSS for Windows 17.0 (Statistical Package for Social Sciences). 
Srednje vrijednosti ispitanika $(\mathrm{n}=283)$ prikazane su u Tablici 5 .

Tablica 5. Aritmetičke sredine i standardne devijacije u upitniku o komunikacijskim vještinama turističkih vodiča

\begin{tabular}{ccc}
\hline Komunikacijske vještine & $\mathrm{M}$ & $\mathrm{SD}$ \\
\hline Verbalna dimenzija (komuniciranje riječima) & & \\
\hline Odabir jezika & 4.08 & 0.99 \\
\hline Prezentiranje kulturne i prirodne baštine & 4.21 & 1.04 \\
\hline Neverbalna dimenzija (komuniciranje tijelom) & & 1.08 \\
\hline Neverbalno ponašanje koje zahtjeva interakciju & 3.82 & 1.19 \\
\hline Vanjski izgled i držanje tijela & 4.01 & \\
\hline
\end{tabular}

Aritmetička sredina skale je 4,03, a standardna devijacija 1,07. Srednje vrijednosti pokazuju da velika većina ispitanika smatra da su turistički vodiči vrlo učinkoviti u provođenju kako verbalnih tako i neverbalnih komunikacijskih vještina. Zanimljivo je kako ispitanici smatraju da su turistički vodiči bolji u komuniciranju riječima nego u komunikaciji tijelom.

Iz podataka prikazanih u Tablici 5. razvidno je da turisti smatraju da turistički vodiči izvrsno prezentiraju kulturnu i prirodnu baštinu na vrlo dobrom engleskom jeziku. Prilikom razgovora i dijeljenja pozitivnih informacija o svojoj zemlji turistički vodiči jasno prezentiraju ideje, pažljivo odabiru riječi, te koriste odgovarajuću gramatiku. Uz to, pokazuju interes o drugim zemljama uz jasan izgovor i izbjegavanje slenga.

Ispitanici koji su sudjelovali u istraživanju smatraju da turistički vodiči vode računa o vanjskom izgledu i držanju. Ovu neverbalnu dimenziju komunikacijske vještine ispitanici su visoko ocijenili. Turisti smatraju da se turistički vodiči ponašaju u skladu s pravilima struke. Najniža vrijednost (3.82) iskazana je za neverbalnu komunikacijsku vještinu koja zahtijeva interakciju. Ljudsko lice šalje velik broj neverbalnih znakova. Pod izrazima lica najvažniji su kontakt očima i osmijeh. Kontakt očima vrlo je važan neverbalni znak. Prema mišljenju turista prilikom vođenja tura, turistički vodiči bi mogli više obratiti pozornost na držanje tijela, ugodan izraz lica, održavati izravan kontakt očima i biti nasmiješeni.

Međusobna povezanost varijabli uključenih $u$ istraživanje istražena je Pearsonovim koeficijentom korelacije. 
Tablica 6. Korelacija između komunikacijskih vještina, te spola i iskustva u radu turističkih vodiča

\begin{tabular}{ccc}
\hline Komunikacijske vještine & $\begin{array}{c}\text { Godine iskustva u radu (turistički } \\
\text { vodič) }\end{array}$ & Spol \\
\hline Verbalna dimenzija & & \\
\hline Odabir jezika & $0.33^{*}$ & 0.20 \\
\hline Prezentiranje kulturne i prirodne baštine & $0.48^{*}$ & 0.28 \\
\hline Neverbalna dimenzija & & $0.30^{*}$ \\
\hline $\begin{array}{c}\text { Neverbalno ponašanje koje zahtjeva } \\
\text { interakciju }\end{array}$ & 0.20 & $0.43^{\star}$ \\
\hline Vanjski izgled i držanje tijela & 0.19 & \\
\hline
\end{tabular}

${ }^{*} p<0,05$

Iz Tablice 6. razvidno je da su Godine iskustva u radu kao turistički vodič povezane s obje verbalne dimenzije komunikacijskih vještina, Prezentiranje kulturne i prirodne baštine $\left(r=0,48^{*}\right)$ te Odabir jezika $\left(r=0,33^{\star}\right)$, a s nijednom neverbalnom dimenzijom gdje se komunikacija bazira na komuniciranju tijelom.

Neverbalne dimenzije komunikacijskih vještina: Neverbalno ponašanje koje zahtijeva interakciju $(r=0,20)$, te Vanjski izgled i držanje tijela turističkih vodiča $(\mathrm{r}=0,19)$ nisu povezane s Godinama iskustva u radu kao turistički vodič. Pregled rezultata korelacijske analize ukazuje na međusobne pozitivne povezanosti Spola s neverbalnim dimenzijama komunikacijskih vještina. Spol korelira s Neverbalnim ponašanjem koje zahtijeva interakciju $\left(r=0,30^{*}\right)$, te $s$ Vanjskim izgledom $\mathrm{i}$ držanjem tijela turističkih vodiča $\left(r=0,43^{\star}\right)$. Zanimljivo je da Spol ne korelira $s$ verbalnim dimenzijama komunikacijskih vještina Prezentiranjem kulturne i prirodne baštine $(r=0,28)$ i Odabirom jezika $(r=0,20)$.

\section{DISKUSIJA}

Kako se na temelju korelacije ne može zaključivati o uzročno posljedičnoj povezanosti između ispitivanih varijabli, mogu se ponuditi tek pretpostavke o mogućim objašnjenjima dobivenih nalaza. Postojeća teorija obogaćena je spoznajom da su komunikacijske vještine povezane s turističkim iskustvom medijatora, osim samo s vjerodostojnosti i izgradnjom međusobnog povjerenja (Chang, 2014).

$\mathrm{Na}$ osnovu rezultata istraživanja možemo zaključiti da je percepcija turista $s$ aspekta godina iskustva u radu kao turističkog vodiča povezana s adekvatnim odabirom riječi i odgovarajućim tonom koji su ključni za uspostavljanje i održavanje 
komunikacije s posjetiteljima. Poruke koje prenose su jasne, korisne i prevedene $\mathrm{u}$ duhu izvornog jezika posjetitelja kako bi se razumjele na pravilan način. Rezultati, također, ukazuju na značajnu međusobnu povezanost između godina iskustva u radu kao turistički vodič i prezentiranja kulturne i prirodne baštine.

Povezanost spola s neverbalnim dimenzijama komunikacijskih vještina, te godina iskustva $s$ obje verbalne dimenzije komunikacijskih vještina predstavlja nadogradnju postojećih teorijskih spoznaja. Brojna recentna istraživanja pokazuju da turizam može biti pogodan za promicanje nekih osobina ženskog spola, npr. ugodnost kod pristupa (Wang, Xu, 2017), ali i vještine u prezentiranju lokalnih tradicija (Masadeh, 2018). Također, angažiranje žena za uloge turističkih vodiča, u posebice siromašnijim sredinama, unaprjeđuje standard obitelji i zapošljivost žena (Pritchard, 2014; ResponsibleTravel.com). Ponegdje se više preferiraju muški vodiči npr. u nesigurnim destinacijama i onima s jakim utjecajem religije i tradicije kao što je to u Brazilu, Iranu, Jordanu (Mahdavi, 2016) što ukazuje na potrebu sagledavanja širih aspekata utjecaja na zadovoljstvo korisnika pri budućim istraživanjima.

Preporuke i mogućnosti poboljšanja rada turističkih vodiča prikazane su Tablicom 7.

Tablica 7. Turistički vodiči - mogućnosti poboljšanja prema stavovima ispitanika

\begin{tabular}{cc}
\hline & Vodiči \\
\hline Verbalna komunikacija & Neverbalna komunikacija \\
\hline $\begin{array}{c}\text { Znanje jezika i timski rad (jasnoća, duh jezika, } \\
\text { korisnost) }\end{array}$ & $\begin{array}{c}\text { Razina interakcije (govor tijela, geste, izrazi lica, } \\
\text { kontakt očima) }\end{array}$ \\
\hline $\begin{array}{c}\text { Komunikacijske i organizacijske vještine } \\
\text { (spremnost i volja za realizacijom očekivanog, } \\
\text { fleksibilnost) }\end{array}$ & $\begin{array}{c}\text { Osjećaj za diskreciju (međusobna udaljenost, } \\
\text { uvažavanje i poštivanje vrijednosti i normi } \\
\text { sugovornika) }\end{array}$ \\
\hline $\begin{array}{c}\text { Poznavanje destinacije (fizička okolina, } \\
\text { prezentacija baštine) }\end{array}$ & Osobni stav (vanjski izgled i držanje) \\
\hline
\end{tabular}

Na temelju rezultata istraživanja može se zaključiti da se odgovorilo na postavljena istraživačka pitanja. Došlo se do spoznaje da neverbalni aspekti komunikacije prožimaju praktički svaki komunikacijski čin, te pritom svi neverbalni kanali dolaze do izražaja; tijelo, lice, glas, izgled, dodir, međusobna udaljenost, te fizička okolina. Analizirajući rezultate korelacija možemo zaključiti, da su ispitanicima koji su sudjelovali u ovom istraživanju vrlo važni aspekti prikladne tjelesne prezentacije turističkih vodiča, kao što su vanjski izgled i držanje tijela. Facijalna ekspresija, kako muških, tako i ženskih turističkih vodiča, jedna je od bitnih stavki u komunikaciji. 
Turistički vodiči trebaju širiti spoznaje o vlastitoj refleksiji prema krajnjim korisnicima (turistima). Pri tome mogu pomoći interdisciplinarni timovi, menadžerski alati, tematske asistencije (hub-ovi) i tehnološke mrežne strukture.

\section{ZAKLJUČAK}

S obzirom da je prelazak iz poznate zone (domicilnog okruženja) u nepoznato (transformativno putovanje) veliki izazov, javljat će se zahtjevi za mentorima medijatorima prije, tijekom i nakon putovanja. Posao vodiča neraskidivo je povezan sa susretom različitih kultura, vjera, mentaliteta i običaja.

Istraživanje ukazuje na potrebu širenja spoznaje o značaju komunikacijskih kompetencija na zadovoljstvo turom, ali i posjetom destinaciji. U radu se rezultatima istraživanja daju odgovori na istraživačka pitanja o tome koliko su turistički vodiči učinkoviti u interpretaciji s aspekta verbalnih i neverbalnih vještina. Prevladava mišljenje da odnos vodiča prema klijentu i dalje treba biti kombinacija jednog i drugog pristupa tj. isti ne smije biti robotiziran, nefleksibilan, hladan i odbojan. Potrebno je fokusirati se na ostvarenje dojma kod klijenta temeljem izražene dobrodošlice, osjećaja ugode, uvažavanja i važnosti (personalizirani pristup). Rezultati istraživanja pokazuju da turisti koji su sudjelovali u ovom istraživanju smatraju da su turistički vodiči učinkoviti u provođenju komunikacijskih vještina, i to kako verbalnih, tako i neverbalnih. Zanimljivo je kako turisti smatraju da su turistički vodiči nešto bolji u verbalnoj komunikaciji. Ista podrazumijeva razgovore u kojima je izgovorena riječ baza komunikacije. Nadalje, smatraju da su manje bolji u neverbalnoj komunikaciji koja uključuje govor tijela, geste, izraze lica, kontakt očima i osobni stav. Korelacijske su analize provedene kako bi se utvrdio međusobni stupanj povezanosti ispitivanih varijabli. Uvidom $\mathrm{u}$ iste zaključilo se da su Godine iskustva u radu kao turistički vodič povezane s obje verbalne dimenzije komunikacijskih vještina dok Spol korelira s neverbalnim dimenzijama komunikacijskih vještina.

Ograničenje rezultata je u ispitivanju stavova dionika na jednom (najviše globalno zastupljenom) stranom jeziku. Također, ispitivanje je provedeno $\mathrm{u}$ periodu smanjene turističke potražnje (rujan) dok se isto treba provesti i u periodu predsezone i visoke sezone (vršnog opterećenja). Tada bi rezultati mogli biti nešto drugačiji i mogli bi se uspoređivati kroz dulji vremenski period. Ispitivanje posjetitelja istarskih destinacija nije jednako provedivo u vršnim opterećenjima destinacije, s obzirom na veliki broj turista, u odnosu na manji broj turista kao i manju opterećenost vodiča kroz dnevne rasporede izvan ljetnog perioda. Dakle, uzorak bi se mogao proširiti i na ispitivanje stavova dionika o vođenju turističkih 
tura na drugim stranim jezicima i na drugim destinacijama. Znanstveni doprinos ovog rada je spoznaja važnosti neverbalnih aspekata komunikacije za posjetitelja sa svrhom unaprjeđenja istih u hrvatskom turizmu. Time je potvrđena sličnost rezultata istraživanja prema Boyes i suradnicima (2009), Tsai i suradnicima (2016), Cheng i suradnicima (2020) koja dokazuju važnost posebice neverbalnih kompetencija u efikasnosti interpretacije turističkih vodiča. Praktične implikacije istraživanja su u potencijalno dodatnoj edukaciji turističkih vodiča kroz transfer znanja u turističku praksu tj. vođenje tura. Buduća istraživanja kvalitativnog tipa trebala bi omogućiti dublji uvid u problematiku istraživanja i time otkloniti prethodno navedena istraživačka ograničenja.

Istraživanja ovog tipa predstavljaju sadašnjost, a posebice budućnost turizma i treba ih intenzivirati. Nedostatak znanstvenih radova na ovu temu u domaćoj znanstvenoj zajednici to i potvrđuje. Važnost izučavanja ove problematike $\mathrm{u}$ hrvatskom turizmu raste posebice zbog rasta kulturnog turizma u nacionalnim i globalnim razmjerima, a time i važnosti prenošenja tradicija pomoću kvalitetne interpretacije (iskusnih medijatora).

Potpora istraživanju: "Rad je izrađen u okviru znanstvenog projekta Turistički razvoj iutjecaji na destinaciju pri Fakultetu ekonomije i turizma "Dr. Mijo Mirković", Sveučilište Jurja Dobrile u Puli. Mišljenja, nalazi i zaključci ili preporuke navedene u ovom radu odnose se na autore i ne odražavaju nužno stajališta Fakulteta ekonomije i turizma "Dr. Mijo Mirković" Pula." Zahvaljujemo Turističkoj zajednici Istarske županije na pomoći u ovom znanstvenom istraživanju. 


\section{LITERATURA}

1. Ap, J., Wong, K.K.F. (2001). Case study on tour guiding: Professionalism, issues and problems. Tourism Management, 22 (5): 551-563. doi: 10.1016/S0261-5177(01)00013-9

2. Bartoluci, M., Budimski, V. (2010). Obrazovni sustav stručnih kadrova za potrebe turizma u Hrvatskoj. Hrvatski znanstveno stručni skup o menadžmentu u turizmu i sportu, 1 (1): 7-19.

3. Black, R., Ham, S. (2005). Improving the quality of tour guiding: Towards a model for tour guide certification. Ecotourism, 4 (3), 178-195. doi: 10.1080/14724040608668442

4. Borrie, B. (1999). Disneyland and Disney World: Constructing the environment, designing the visitor experience. Society and Leisure, 22 (1): 71-82.

5. Boyes, C. (2009). Jezik tijela. Zagreb: Kigen.

6. Boyle, A., Arnott, A., Cooper, C. (2004). What Tour Guide Stories Can Tell us about Learning, Education and Training: A Case Study in the Top End of the Northern Territory. Council for Australian Tourism and Hospitality Education (CAUTHE) conference (86-94), University of Queensland. Brisbane, Qld, Australia. 10-13 February.

7. Bowie, D., Chang, J.C. (2005). Tourist satisfaction: A view from a mixed international guided package tour. Journal of Vacation Marketing, 11: 303-322. doi: 10.1177/1356766705056628

8. Burgoon, J. K. (2016). Nonverbal Communication. London: Routledge.

9. Chang, K.C. (2014). Examining the Effect of Tour Guide Performance, Tourist Trust, Tourist Satisfaction, and Flow Experience on Tourists' Shopping Behavior, Asia Pacific Journal of Tourism Research, 19 (2): 219-247. doi: 10.1080/10941665.2012.739189

10. Cheng, T., Chen, M., Wu, C. (2020). Tour Conductor Playfulness: Conceptualizing and Scale Development. Journal of Travel Research. doi.org/10.1177/0047287519888284

11. Cohen, E. (1985). The tourist guide: The origins, structure and dynamics of a role. Annals of Tourism Research, 12 (1): 5-29. doi: 10.1016/0160-7383(85)90037-4

12. Domšić, L. (2013). Cultural heritage and identity in the contemporary tourism development, Diem: Dubrovnik International Economic Meeting, 1 (1). Dostupno na: https://hrcak.srce. $\mathrm{hr} / 161546$

13. Ferguson, M., Walby, K., Piche, J. (2016). Tour Guide Styles and Penal History Museums in Canada. International Journal of Tourism Research, 18 (5): 477-485.

14. Gali, N., Aulet, S. (2019). Tourists' space-time behavior in heritage places: Comparing guided and nonguided visitors. International Journal of Tourism Research, 21 (3): 388-399. https://doi. org/10.1002/jtr.2270

15. Geva, A., Goldman, A. (1991). Satisfaction measurement in guided tours. Annals of Tourism Research, 18 (2): 177-185. doi: 10.1016/0160-7383(91)90002

16. Gregorić, M., Somođi, Đ., Obadić, L. (2017). Cjeloživotno obrazovanje turističkih vodiča s ciljem podizanja kvalitete u turizmu Republike Hrvatske. Obrazovanje za poduzetništvo - E4E: znanstveno stručni časopis o obrazovanju za poduzetništvo, 7 (1): 161-177.

17. Gorenak, M., Gorenak, I. (2012). Izazovi u edukaciji turističkih vodiča i organizatora turizma. Informatologia, 45 (4): 287-296. 
18. Heung, V. C. S. (2008). Effects of tour leader's service quality on agency's reputation and customers' word-of-mouth. Journal of Vacation Marketing, 14 (4): 305-315. doi: $10.1177 / 1356766708094752$

19. Hsu, C. H., Chan, A., Huang, S. (2009). Tour Guide Performance and Tourist Satisfaction: a Study of the Package Tours in Shanghai. Journal of Hospitality and Tourism Research 34 (1): 3-33. https://doi.org/10.1177/1096348009349815

20. Huang, R., Wang, W. (2007). An investigation of the intercultural competence of tour guides in Great Britain. Acta Turistica. 19 (2): 126-149.

21. Hrvatska turistička zajednica, 2019, https://htz.hr/hr-HR/informacije-o-trzistima/informacije-otijeku-sezone/arhiva-2019.

22. Kang, M., Gretzel, U. (2012). Effects of podcast tours on tourist experiences in a national park. Tourism Management, 33, 440-455. https://doi.org/10.1016/j.tourman.2011.05.005

23. Kendon, A. (1967). Some functions of gaze-direction in social interaction. Acta Psychologica, 26, 22-63. https://doi.org/10.1016/0001-6918(67)90005-4.

24. Le Nguyen, H. L. (2015). The impacts of tour guide performance on foreign tourist satisfaction and destination loyalty in Vietnam, Doctoral dissertation. University of Western Sydney.

25. Lopez, E. M. (1980). The effect of leadership style on satisfaction levels of tour quality. Journal of Travel Research, 18 (4): 20-23. doi: 10.1177/004728758001800403

26. Mak, A. H. N, Wong, K. K. H., Chang, R. C. Y. (2011). Factors affecting the service quality of the tour guiding profession in Macau, International Journal of Tourism Research, 12 (3): 205-218.

27. Mahdavi, Z.M. (2016). Iranian Female tour guides' perceptions of working in the tourism industry. Dostupno na: http://umu.divaportal.org/smash/get/diva2:958214/FULLTEXT01. pdf\%2006.06.2017\%2021:28.

28. Malitoni Chilembwe, J., Mweiwa, V. (2014). Tour guides: are they tourism promoters and developers? Case study of Malawi. International Journal of Research in Business Management, 2 (9): 29-46.

29. Martin, J., Hammer, M., Bradford, L. (1994). The influence of cultural and situational contexts on Hispanic and non-Hispanic communication competence behaviours, Communication Quarterly, 42 (2): 160-179. https://doi.org/10.1080/01463379409369924.

30. Masadeh, M. (2018). Female Tourist Guides in Jordan: Why So Few?, European Journal of Social Sciences, 56 (2): 89-102.

31. Mizzi, G. (2009). Profesija, kvalifikacija, obuka, supervizija i usklađivanje Smjernice 2005/36/EC Turističko vođenje. Acta turistica nova, 3(2): 329-335.

32. Mossberg, L. L. (1995). Tour leaders and their importance in charter tours. Tourism Management, 16 (6), 437-445. doi: 10.1016/0261-5177(95)00052-P

33. Ön Esen, F., Gülmez, M. (2017). View of Academicians and Professional Tourist Guides on Domestic Practice Tours. International Journal of Commerce and Management 5 (7):222-250.

34. Pearce, P. (2011). Tourist behaviour in the contemporary world. Bristol: Channel View Publications.

35. Poria, Y., Biran, A., Reichel, A. (2009). Visitors' Preferences for Interpretation at Heritage Sites, Journal of Travel Research, 48 (1): 92-105. doi: 10.1177/0047287508328657. 
36. Pritchard, A (2014). Gender and Feminist Perspectives in Tourism Research in The Wiley Blackwell Companion to Tourism. Alan A. Lew, C. Michael Hall Allan M. Williams (eds.), Wiley online library. https://doi.org/10.1002/9781118474648.ch25.

37. Pšunder, M. (2002). Global communication, Informatologia, 35 (1): 48-59.

38. Reisinger, Y. (2013). Transformational tourism. Boston: CABI.

39. ResponsibleTravel.com, Holidays with female guides. Dostupno na: https://www. responsibletravel.com/holidays/female-guides/travel-guide.

40. Ritchie, J. R. B., Hudson, S. (2009). Understanding and meeting the challenge of consumer/tourist experience research. International Journal of Tourism Research, 11(2): 111-126. doi: 10.1002/ jtr.721.

41. Rijavec, M., Miljković, D. (2009). Pozitivna psihologija na poslu. Zagreb: IEP.

42. Sharma, S. (2013). Analyzing the role of tour guides: A review of literature, Indian Institute of Tourism and Travel Management.

43. Smith, M. L., Cottrelll, G. W., Gosselin, F., Schyns, P. G. (2005). Transmitting and Decoding Facial Expressions. Psychological Science, 16 (3): 184-189. doi: 10.1111/j.0956-7976.2005.00801.x

44. Tilotama, P. P. (2019). Tour guide performace competencies influencing the tourists' satisfaction. University Muhammadiyah of Purwokerto.

45. Tomljenović, R., Ateljević, I. (2015). Transformative tourism: Working definition and typology of transformative travel experience, doi: 10.13140/RG.2.1.1758.6325

46. Tsai, C., Wang, M., Tseng, H. (2016). The Impact of Tour Guides' Physical Attractiveness, Sense of Humor, and Seniority on Guide Attention and Efficiency, Journal of Travel \& Tourism Marketing, 33 (6): 824-836. doi: 10.1080/10548408.2015.1068264.

47. Tu, H., Guo, W., Xiao, X. (2019). The Relationship between Tour Guide Humor and Tourists' Behavior Intention: A Cross-Level Analysis. Journal of Travel Research. doi. org/10.1177/0047287519883033.

48. Wang, H., Xu, H. (2017). Gender Strategies at Work: Informal Female Tour Guides in Yangshuo West Street. Journal of China Tourism Research, 14 (2): 1-17. doi: $10.1080 / 19388160.2018 .1517625$

49. Weiler, B., Black, R. (2014). The changing face of the tour guide: one-way communicator to choreographer to co-creator of the tourist experience, Tourism Recreation Research, 40 (3): 364378. https://doi.org/10.1080/02508281.2015.1083742

50. Widtfeldt Meged, J. (2010). The guided tour - A co-produced tourism perfomance, Department of Environmental, social and Spacial changes, Roskilde University.

51. Zhang, H. Q., Chow, I. (2004). Application of importance-performance model in tour guides' performance: Evidence from mainland Chinese outbound visitors in Hong Kong. Tourism Management, 25 (1): 81-91. doi: 10.1016/S0261-5177(03)00064-5.

52. Zillinger, M., Jonasson, M., Adolfsson, P. (2012). Guided tours and tourism. Scandinavian Journal of Hospitality and tourism. 12 (1): 1-7. doi: 10.1080/15022250.2012.660314. 


\title{
THE DEGREE OF TOURIST SATISFACTION WITH TOURIST GUIDES' COMMUNICATION COMPETENCIES
}

\begin{abstract}
This pilot research analyses the correlations between tourist guides'communication competencies and tourists' satisfaction with guided tours in several towns of the Istria County. Another objective of the paper is to establish the correlation between the communication skills of the guides regarding their gender and years of professional experience. The aim of the research is to point out to the mistakes of their verbal and nonverbal competence during tour guiding. For the purposes of the research, data from 283 respondents (tourists) of selected destinations were collected. Respondents came from different emitting markets. The results of the research point to the need to improve the guides' verbal skills, as well as nonverbal communication such as accessibility and the ability to develop friendly relationships with the client. The contribution of the research is to improve knowledge in the field of interdisciplinary research (tourism and culture). The results of the research represent the transfer of knowledge about the expected competencies of the examinees and the impact on customer satisfaction, in order to improve the quality of work of mediators in tourism and destination promoters.
\end{abstract}

Keywords: tourist guide, verbal competencies, nonverbal competencies, tourists, degree of satisfaction. 